V.F. Bolyukh, Yu.V. Kashansky, I.S. Schukin

\title{
FEATURES OF EXCITATION OF A LINEAR ELECTROMECHANICAL CONVERTER OF INDUCTION TYPE FROM AN AC SOURCE
}

Purpose. The purpose of the article is to establish the basic laws of operation of induction-type linear electromechanical converter (LEMC) during operation in high-speed and shock-power modes and excitation from an AC source of increased frequency. Methodology. With the help of a mathematical model, the regularities of the course of processes in a LEMC, excited from an AC source, were established when working with shock-power and high-speed modes. The solutions of the equations of the mathematical model, which describe interrelated electrical, magnetic, mechanical and thermal processes, are presented in a recurrent form. Results. It was found that when the LEMC operates in the shock-power mode, the maximum value of the current in the inductor winding occurs in the first half-period, and in the inhibited armature winding in the second half-period. The electrodynamic force changes at twice the frequency, taking on both positive and negative values. Since the positive values exceed the negative ones, the magnitude of the impulse of the electrodynamic force increases with each period of the force. Depending on the initial voltage phase, the relative change in the magnitude of the force impulse is $1.5 \%$. It was found that when the LEMC operates in high-speed mode, the current in the inductor winding in the first half-period has the greatest value, but after several periods it takes on a steady state. The temperature rise of the inductor winding increases with the time of connection to the AC source, and the temperature rise of the armature winding has the nature of saturation. The electrodynamic force has an oscillatory character with strong damping and a significant predominance of the positive component. Depending on the initial phase of the voltage, the relative change in the maximum speed of the armature winding is $2.5 \%$. Originality. For the first time, a mathematical model of the LEMC, excited from an AC source, was developed, the solutions of the equations of which describe the interrelated electrical, magnetic, mechanical and thermal processes. For the first time, the regularities of the course of processes in LEMC were established when working with shockpower and high-speed modes. Practical value. The characteristics of LEMC are obtained, which determine the efficiency of work in shock-power and high-speed modes. It is shown that the initial voltage phase has no significant effect on the power, high-speed thermal performance of the converter excited from an alternating current source. References 16, figures 5.

Key words: linear electromechanical induction-type converter, mathematical model, high-speed and shock-power operation mode, alternating current source, maximum speed, electrodynamic force impulse.

Розроблена ланцюгова математична модель лінійного електромеханічного перетворювача індукційного типу при збудженні від джерела змінного струму, в якій рімення рівнянь, що описують взаємопов'язані електричні, магнітні, механічні та теплові прочеси, які представлені в рекурентному вигляді. Встановлено, що при роботі перетворювача в ударно-силовому режимі електродинамічна сила змінюється з подвійною частотою, приймаючи як позитивні, так $i$ негативні значення. Позитивні значення сили перевищують негативні i величина імпульсу електродинамічної сили 3 кожним періодом підвищується. В залежності від початкової фази напруги відносна зміна величини імпульсу сили складає 1,5\%. При роботі перетворювача в швидкісному режимі максимальний струм в обмотиі індуктора в перший півперіод має найбільше значення, але через декілька періодів приймає постійне значення. В залежності від початкової фази напруги відносна зміна максимальної швидкості обмотки якоря складає 2,5 \%. Бібл. 16, рис. 5.

Ключові слова: лінійний електромеханічний перетворювач індукційного типу, математична модель, швидкісний і ударно-силовий режим роботи, джерело змінного струму, максимальна швидкість, імпульс електродинамічної сили.

Разработана иееная математическая модель линейного электромеханического преобразователя индукиионного типа при возбуждении от источника переменного тока, в которой решения уравнений, описываюшие взаимосвязанные электрические, магнитные, механические и тепловые процессы, представлены в рекуррентном виде. Установлено, что при работе преобразователя в ударно-силовом режиме электродинамическая сила изменяется с удвоенной частотой, принимая как положительные, так и отрицательные значения. Положительные значения силы превышают отрицательные и величина импульса электродинамической силы с каждым периодом увеличивается. В зависимости от начальной фазы напряжения относительное изменение величины импульса силь составляет 1,5 \%. При работе преобразователя в скоростном режиме максимальный ток в обмотке индуктора в первый полупериод имеет наибольщее значение, но через несколько периодов принимает постоянное значение. В зависимости от начальной фазы напряжения относительное изменение максимальной скорости обмотки якоря составляет 2,5%. Библ. 16, рис. 5.

Ключевые слова: линейный электромеханический преобразователь индукционного типа, математическая модель, скоростной и ударно-силовой режим работы, источник переменного тока, максимальная скорость, импульс электродинамической силы.

Introduction. Linear electromechanical converters (LEMCs) of induction type are used to accelerate the actuation element to high speed in a short active section and to create powerful force pulses on the object of influence with a slight movement of the specified element [1-4]. Such converters operate in high-speed (accelerating) and shock-power modes. They are used as actuating elements of electromechanical accelerators and shock-power devices [5-7].
In LEMC of induction type, a movable armature, made in the form of a single- or multi-turn short-circuited winding, inductively interacts with the stationary winding of the inductor. In a converter of coaxial configuration, the windings are made in the form of discs. The armature winding is installed and moves axially relative to the inductor winding. When the inductor winding is excited from the power source, the current flowing in it through

(c) V.F. Bolyukh, Yu.V. Kashansky, I.S. Schukin 
the magnetic field induces a current in the armature winding. The resulting electrodynamic forces between the windings are transmitted to the actuation by means of the movable armature winding.

The most common excitation of LEMC is from a high-voltage capacitive energy storage [2, 8]. However, this requires special high-voltage equipment and appropriate winding design. In addition, such excitation occurs over a relatively short period of time, which can limit a number of performance and technical applications of the converter.

At one time, other sources of excitation of LEMC of the induction type were considered, for example, inductive and of alternating current of increased frequency [9]. In [10], an AC source was investigated for an electromechanical accelerator of a cylindrical configuration, in which the armature winding moves coaxially inside the inductor winding. The following options were considered:

1) excitation from a source of increased frequency;

2) excitation from a source, the frequency of which increases as the armature winding accelerates;

3 ) winding of the inductor winding with an increasing step, which is excited from a source of constant frequency.

Option No. 2 requires a special generator. Option No. 3 is appropriate only for an accelerator, in which the armature winding moves inside the inductor winding. Option No. 1 was developed in [11], where an electromechanical accelerator was described, in which the armature winding was accelerated inside a row of axially installed sections of the inductor winding. The sections of the inductor winding, as the armature winding moved, were sequentially connected to the sections of the AC source, in each of which the frequency of the alternating current was constant, but increased in relation to the frequency of the previous section. Note that such an excitation system is complex and requires a complex switching system.

All studies of excitation sources concerned LEMC operating in high-speed mode, in which the time of effective interaction of the accelerated armature winding with the inductor winding is insignificant. But when operating in the shock-power mode, the indicated interaction time can be significant, being limited by other factors, for example, thermal one.

The goal of the paper is the establishment of the basic laws of operation of induction-type LEMC when operating in high-speed and shock-power modes and excitation from an AC source of increased frequency.

LEMC mathematical model. Consider a mathematical model of an induction-type LEMC in a high-speed mode, in which the magnetic coupling between the windings changes during the excitation of the inductor winding. In this model, we use the lumped parameters of the fixed inductor winding and the accelerated armature winding [12]. To take into account the interrelated electrical, magnetic, mechanical and thermal processes, as well as a number of nonlinear dependences, for example, resistance on temperature, the solution of equations describing these processes will be presented in a recurrent form [9, 13].

To calculate the indicators and time characteristics of LEMC, we use a cyclic algorithm. For this, the workflow is divided into a number of numerically small time intervals $\Delta t=t_{k+1}-t_{k}$, within which all quantities are considered unchanged. On the $k$-th cycle, using the parameters calculated at the time $t_{k}$ as initial values, the parameters are calculated at the time $t_{k+1}$.

To determine the currents over the time interval $\Delta t$, we use linear equations with unchanged parameter values. We choose a small value of the calculated step $\Delta t$ so that it does not have a significant effect on the calculation results on a computer, while ensuring the required accuracy.

Initial conditions of the mathematical model are: $T_{n}(0)=T_{0}$ is the temperature of the $n$-th winding; $i_{n}(0)=0$ is the current of the $n$-th winding; $h_{z}(0)=h_{z 0}$ is the distance between the windings; $u(0)=U_{m} \sin \psi_{u}$ is the voltage of the AC source; $v_{z}(0)=0$ is the speed of the armature winding along the $z$ axis.

Since the inductor and the armature are made in the form of multi-turn tightly wound windings, it is advisable for them to use the concepts of inductances and mutual inductance. The change in the spatial position of the armature winding is taken into account by the change in flux linkage $\Psi$ between the windings [14]:

$$
\frac{d \Psi_{n}}{d t}=M(z) \frac{d i_{n}}{d t}+v_{z}(t) \cdot i_{n} \frac{d M}{d z},
$$

where $n=1,2$ are the indices of the inductor and armature windings, respectively; $M(z)$ is the mutual inductance between the windings; $v_{z}$ is the speed of movement of the armature winding along the $z$ axis; $i_{n}$ is the current of the $n$-th winding.

In this case, the electrical processes in the LEMC windings can be described by the system of equations:

$$
\begin{gathered}
R_{1}\left(T_{1}\right) i_{1}+L_{1} \frac{d i_{1}}{d t}+M_{12}(z) \frac{d i_{2}}{d t}+i_{2} v_{z}(t) \frac{d M_{12}}{d z}=u(t), \\
R_{2}\left(T_{2}\right) i_{2}+L_{2} \frac{d i_{2}}{d t}+M_{21}(z) \frac{d i_{1}}{d t}+i_{1} v_{z}(t) \frac{d M_{21}}{d z}=0,
\end{gathered}
$$

where $u(t)=U_{m} \sin \left(\omega t+\psi_{u}\right)$ is the power supply voltage; $R_{n}, L_{n}, T_{n}$ are the active resistance, inductance, temperature and current of the $n$-th winding, respectively.

Let's introduce the notation:

$$
\begin{gathered}
R_{1}=R_{1}\left(T_{1}\right) ; R_{2}=R_{2}\left(T_{2}\right) ; \\
M=M_{12}(z)=M_{21}(z) ; v_{z}=v_{z}(t) ; u=u(t) .
\end{gathered}
$$

We will find solutions for currents in the form:

$$
\begin{aligned}
& i_{1}=\frac{u}{R_{1}}-\beta \frac{i_{2}}{R_{1}}+A_{11} \exp \left(\alpha_{1} t\right)+A_{12} \exp \left(\alpha_{2} t\right), \\
& i_{2}=-\beta \frac{i_{1}}{R_{1}}+A_{21} \exp \left(\alpha_{1} t\right)+A_{22} \exp \left(\alpha_{2} t\right),
\end{aligned}
$$

where $\quad \alpha_{1,2}=-0.5 \varsigma \chi^{-1} \pm\left\{0.25 \varsigma^{2} \chi^{-2}-\left\lfloor R_{1} R_{2}-\beta^{2}\right\rfloor \chi^{-1}\right\}$ are the roots of the characteristic equation for the free component described by the differential equation

$$
\begin{gathered}
\chi \frac{d^{2} i_{1}}{d t^{2}}+\varsigma \frac{d i_{1}}{d t}+\left(R_{1} R_{2}-\beta^{2}\right) i_{1}=0 \\
\beta=v_{z} \frac{d M}{d z} ; \varsigma=L_{1} R_{2}+L_{2} R_{1}-2 \beta M ; \chi=L_{1} L_{2}\left(1-K_{M}^{2}\right) ;
\end{gathered}
$$


$K_{M}=M\left(L_{1} L_{2}\right)^{-0.5}$ is the magnetic coupling coefficient between windings; $A_{11}, A_{12}, A_{21}, A_{22}$ are the arbitrary constants determined at time $t_{k}$ for the free component of currents equal to

$$
\begin{gathered}
A_{1 l}=\frac{\alpha_{m}\left[i_{2}\left(t_{k}\right) \beta R_{1}^{-1}-u\left(t_{k}\right) R_{1}^{-1}+i_{1}\left(t_{k}\right)\right]-\Xi}{\left(\alpha_{m}-\alpha_{l}\right) \exp \left(\alpha_{l} t_{k}\right)} ; \\
A_{2 l}=\frac{\alpha_{m}\left[i_{2}\left(t_{k}\right)+i_{1}\left(t_{k}\right) \beta R_{2}^{-1}\right]-\Omega}{\left(\alpha_{m}-\alpha_{l}\right) \exp \left(\alpha_{l} t_{k}\right)},
\end{gathered}
$$

where $l=1,2 ; m=3-l$;

$$
\begin{aligned}
& \Xi=\frac{1}{L_{1}\left(1-K_{M}^{2}\right)}\left\{u\left(t_{k}\right)+i_{1}\left(t_{k}\right)\left(\beta \frac{M}{L_{2}}-R_{1}\right)+\right. \\
& \left.+i_{2}\left(t_{k}\right)\left(\frac{M R_{2}}{L_{2}}-\beta\right)\right\} ; \\
& \Omega=\frac{1}{L_{2}\left(1-K_{M}^{2}\right)}\left\{i_{2}\left(t_{k}\right)\left(\beta \frac{M}{L_{1}}-R_{2}\right)-u\left(t_{k}\right) \frac{M}{L_{1}}+\right. \\
& \left.+i_{1}\left(t_{k}\right)\left(\frac{M R_{1}}{L_{1}}-\beta\right)\right) .
\end{aligned}
$$

In the final form, the currents in the LEMC windings are described by the expressions:

$$
\begin{aligned}
& i_{1}\left(t_{k+1}\right)=-\frac{i_{2}\left(t_{k}\right) v_{z}\left(t_{k}\right)}{R_{1}} \frac{d M}{d z}+\left(u\left(t_{k}\right)-R_{1} i_{1}\left(t_{k}\right)-i_{2}\left(t_{k}\right) v_{z}\left(t_{k}\right) \times\right. \\
& \left.\times \frac{d M}{d z}\right) \frac{\alpha_{1} \exp \left(\alpha_{2} \Delta t\right)-\alpha_{2} \exp \left(\alpha_{1} \Delta t\right)}{R_{1}\left(\alpha_{2}-\alpha_{1}\right)}+\frac{u\left(t_{k}\right)}{R_{1}}+ \\
& +\frac{\exp \left(\alpha_{2} \Delta t\right)-\exp \left(\alpha_{1} \Delta t\right)}{L_{1} L_{2}\left(\alpha_{2}-\alpha_{1}\right)\left(1-K_{M}^{2}\right)}\left\{u\left(t_{k}\right) L_{2}+\left[v_{z}\left(t_{k}\right) M \frac{d M}{d z}-R_{1} L_{2}\right] \times\right. \\
& \left.\times i_{1}\left(t_{k}\right)+\left[R_{2} M-v_{z}\left(t_{k}\right) L_{2} \frac{d M}{d z}\right] i_{2}\left(t_{k}\right)\right\} ; \\
& i_{2}\left(t_{k+1}\right)=-\frac{i_{1}\left(t_{k}\right) v_{z}\left(t_{k}\right)}{R_{2}} \frac{d M}{d z}+\left[i_{2}\left(t_{k}\right)+\frac{i_{1}\left(t_{k}\right) v_{z}\left(t_{k}\right)}{R_{2}} \frac{d M}{d z}\right] \times \\
& \times \frac{\alpha_{2} \exp \left(\alpha_{1} \Delta t\right)-\alpha_{1} \exp \left(\alpha_{2} \Delta t\right)}{\alpha_{2}-\alpha_{1}}+\frac{\exp \left(\alpha_{2} \Delta t\right)-\exp \left(\alpha_{1} \Delta t\right)}{L_{1} L_{2}\left(\alpha_{2}-\alpha_{1}\right)\left(1-K_{M}^{2}\right) \times} \\
& \times\left\{i_{1}\left(t_{k}\right)\left[R_{1} M-v_{z}\left(t_{k}\right) L_{1} \frac{d M}{d z}\right]-u\left(t_{k}\right) M+i_{2}\left(t_{k}\right) \times\right. \\
& \left.\times\left[v_{z}\left(t_{k}\right) M \frac{d M}{d z}-R_{2} L_{1}\right]\right\},
\end{aligned}
$$

where $u\left(t_{k}\right)=U_{m} \sin \left(\omega t_{k}+\psi_{u}\right) ; \Delta t=t_{k+1}-t_{k}$.

The value of the displacement of the armature winding together with the actuation element relative to the stationary inductor winding can be represented as a recurrent relation [15]:

$$
h_{z}\left(t_{k+1}\right)=h_{z}\left(t_{k}\right)+v_{z}\left(t_{k}\right) \Delta t+\vartheta \cdot \Delta t^{2} /\left(m_{a}+m_{2}\right),
$$

where $v_{z}\left(t_{k+1}\right)=v_{z}\left(t_{k}\right)+\vartheta \cdot \Delta t /\left(m_{a}+m_{2}\right)$ is the speed of the armature winding together with the actuation element;

$$
\vartheta=f_{z}(z, t)-K_{T} v_{z}\left(t_{k}\right)-0,125 \pi \gamma_{a} \beta_{a} D_{e 2}^{2} v_{z}^{2}\left(t_{k}\right)
$$

$f_{z}(z, t)=i_{1}\left(t_{k}\right) i_{2}\left(t_{k}\right) \frac{d M}{d z}(z)$ is the instantaneous value of the axial electrodynamic force between the windings; $m_{2}$, $m_{a}$ is the mass of the armature winding and the actuation element, respectively; $h_{z}$ is the value of displacement of the armature winding; $K_{T}$ is the coefficient of dynamic friction; $\gamma_{a}$ is the density of the medium of moving; $\beta_{a}$ is the coefficient of aerodynamic resistance; $D_{e 2}$ is the outer diameter of the actuation element.

When the LEMC operates in the shock-power mode, there is a thermal contact between the windings through an insulating pad. In this case, the temperature of the $n$-th winding can be described by the recurrence relation [16]:

$$
\begin{aligned}
& T_{n}\left(t_{k+1}\right)=T_{n}\left(t_{k}\right) \xi+(1-\xi)\left[\pi^{-1} i^{2}\left(t_{k}\right) R_{n}\left(T_{n}\right)\left(D_{e n}^{2}-D_{i n}^{2}\right)^{-1}+\right. \\
& \left.+0,25 \pi T_{0} D_{e n} H_{n} \alpha_{T n}+T_{m}\left(t_{k}\right) \lambda_{a}(T) d_{a}^{-1}\right] \times \\
& \times\left\{0,25 \pi \alpha_{T n} D_{e n} H_{n}+\lambda_{a}(T) d_{a}^{-1}\right\}^{-1}, \\
& \text { where } \xi=\exp \left\{-\frac{\Delta t}{c_{n}\left(T_{n}\right) \gamma_{n}}\left(0,25 D_{e n} \alpha_{T n}+\frac{\lambda_{a}(T)}{d_{a} H_{n}}\right)\right\} ;
\end{aligned}
$$

$\lambda_{a}(T), d_{a}$ are the thermal conductivity and the thickness of the pad, respectively; $D_{e n}, D_{i n}$ are the outer and inner diameters of the $n$-th winding, respectively; $\alpha_{T n}, c_{n}$ are the heat transfer coefficient and heat capacity of the $n$-th winding, respectively.

When the LEMC operates in high-speed mode, the temperature of the $n$-th winding can be described by the recurrent relation:

$$
\begin{aligned}
& T_{n}\left(t_{k+1}\right)=T_{n}\left(t_{k}\right) \chi+(1-\chi)\left[T_{0}+4 \pi^{-2} i^{2}\left(t_{k}\right) \times\right. \\
& \left.\times R_{n}\left(T_{n}\right) \alpha_{T n}^{-1} D_{e n}^{-1} H_{n}^{-1}\left(D_{e n}^{2}-D_{i n}^{2}\right)^{-1}\right],
\end{aligned}
$$

where $\chi=\exp \left\{-0,25 \Delta t D_{e n} \alpha_{T n} c_{n}^{-1}\left(T_{n}\right) \gamma_{n}^{-1}\right\}$.

When implementing equations (9) - (13) on a computer, a cyclic algorithm is used, in which at each numerically small calculation step, the values of the currents $i_{n}$, temperatures $T_{n}$, resistances $R_{n}\left(T_{n}\right)$ of the windings, the thermal conductivity of the pad $\lambda_{a}(T)$, the values of axial electrodynamic force $f_{z}(z, t)$, speed $v_{z}$ and displacement $h_{z}$ of the armature winding, mutual inductance $M(z)$ between the windings are sequentially calculated.

The main parameters of the LEMC. Consider a LEMC of the induction type, in which the inductor winding $(n=1)$ and the armature winding $(n=2)$ are made in the form of disk coils. The windings are tightly wound with $0.9 \mathrm{~mm}$ copper wire. The number of turns of the inductor winding $N_{1}=450$ and the armature winding $N_{2}=180$. The outer diameter of the windings is $D_{e n}=100 \mathrm{~mm}$, their inner diameter is $D_{i n}=10 \mathrm{~mm}$. The axial height of the inductor winding is $H_{1}=10 \mathrm{~mm}$, of the armature winding is $H_{2}=4 \mathrm{~mm}$. The windings are made in the form of massive disks by impregnation and subsequent hardening of epoxy resin. The windings are installed coaxially so that the initial distance between them is $h_{z 0}=0.5 \mathrm{~mm}$. The power supply is characterized by frequency of $100 \mathrm{~Hz}$ and an amplitude of $U_{m}=300 \mathrm{~V}$.

Consider the duration of the connection time of the inductor winding to the source $t=50 \mathrm{~ms}$. Let us estimate the efficiency of the LEMC when operating in a highspeed mode (mass of the actuation element $m_{a}=0.25 \mathrm{~kg}$ ) by the value of the maximum speed $V_{m}$, and when operating in the shock-power mode by the value of the impulse of the electrodynamic force $P_{z}=\int f_{z}(z, t) d t$ 
(we assume that there is no displacement of the armature winding) with minimal rise of the winding temperatures $\theta_{n}=T_{n}-T_{0}$.

Consider the electrical and thermal characteristics of the LEMC when the inductor winding is connected to an $\mathrm{AC}$ source and there is no armature winding, assuming $\psi_{u}=0$ (Fig. 1).

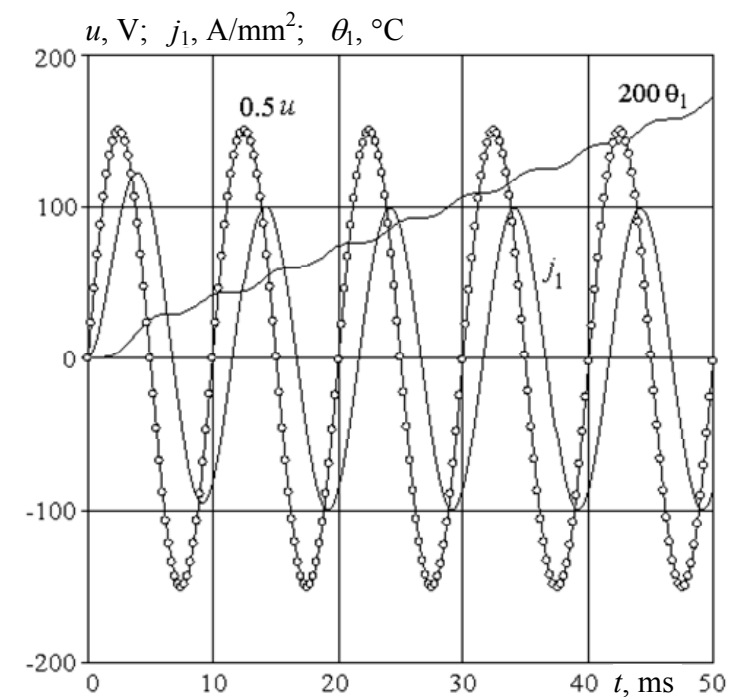

Fig. 1. Electrical and thermal characteristics of LEMC in the absence of the armature winding

The maximum current density in the inductor winding $j_{1}$ in the first half-period is $24 \%$ higher than during subsequent steady-state oscillations. After each half-period of oscillations, an increase in the temperature rise $\theta_{1}$ is observed. By the end of the considered time interval $t=50 \mathrm{~ms}$, the temperature rise of the inductor winding is $\theta_{1}=0.86^{\circ} \mathrm{C}$.

Excitation of LEMC in shock-power mode. Let us consider the excitation of LEMC in the shock-power mode with the armature winding inhibited. Due to the induction effect of the inductor winding on the armature winding, current with density $j_{2}$ flows in the latter (Fig. 2,a).

The induced current in the armature winding has a phase shift with respect to the current in the inductor winding. Compared to operation in the absence of the armature winding, the maximum current density in the inductor winding $j_{1}$ increases by $6.7 \%$. In the first halfperiod, the current density in the armature winding takes the smallest negative value, but already in the second half-period, the largest positive value $j_{2}=121.3 \mathrm{~A} / \mathrm{mm}^{2}$ appears. The rise of the temperature of the inductor winding $\theta_{1}$ by the end of the considered time interval increases by $18.5 \%$ compared to the operation of the LEMC in the absence of the armature winding. The temperature rise of the armature winding is practically the same as that of the inductor winding and is $\theta_{2}=1.03{ }^{\circ} \mathrm{C}$.

Due to the phase shift between the winding currents, the electrodynamic force changes with a doubled frequency practically according to a sinusoidal law, taking both positive (repulsive) and negative (attractive) values (Fig. 2,b).
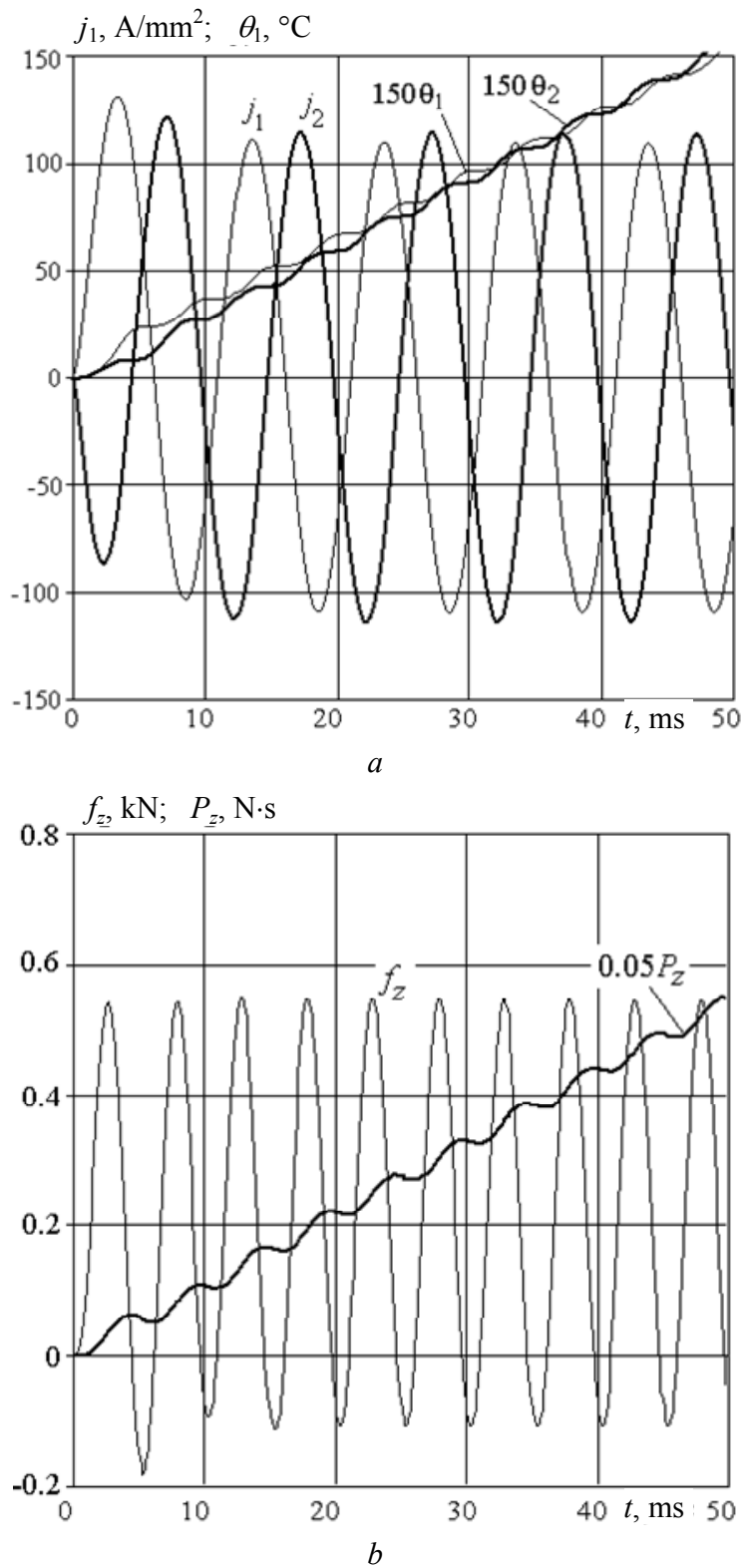

Fig. 2. Electrical, thermal $(a)$ and power $(b)$ characteristics of LEMC when excited in shock-force mode

Positive force values (currents in the windings have opposite directions) are several times higher than negative values (currents have the same directions). The maximum value of the force of the first positive oscillation is $f_{z}=0.542 \mathrm{kN}$, slightly increasing in subsequent half periods. The value of the first negative oscillation is maximum and is $0.182 \mathrm{kN}$, subsequently decreasing by $67 \%$. Since positive oscillations of the force prevail in magnitude over negative ones, the value of the impulse of the electrodynamic force $P_{z}$ increases with each period of the force $f_{z}$, reaching the value $P_{z}=10.98 \mathrm{~N} \cdot \mathrm{s}$ by the end of the considered time interval. At positive values of the force $f_{z}$, the value of the impulse of the force $P_{z}$ increases, and at negative values of the force, the value of $P_{z}$ has characteristic decreases.

The initial phase of the voltage at the moment of connecting the LEMC to the AC source can be in the range $\psi_{u} \in\left(0 ; 180^{\circ}\right)$. The influence of the initial phase of the voltage on the values of the temperature rises of the 
windings and the impulse of the electrodynamic force for the considered time interval $t=50 \mathrm{~ms}$ is shown in Fig. 3 .

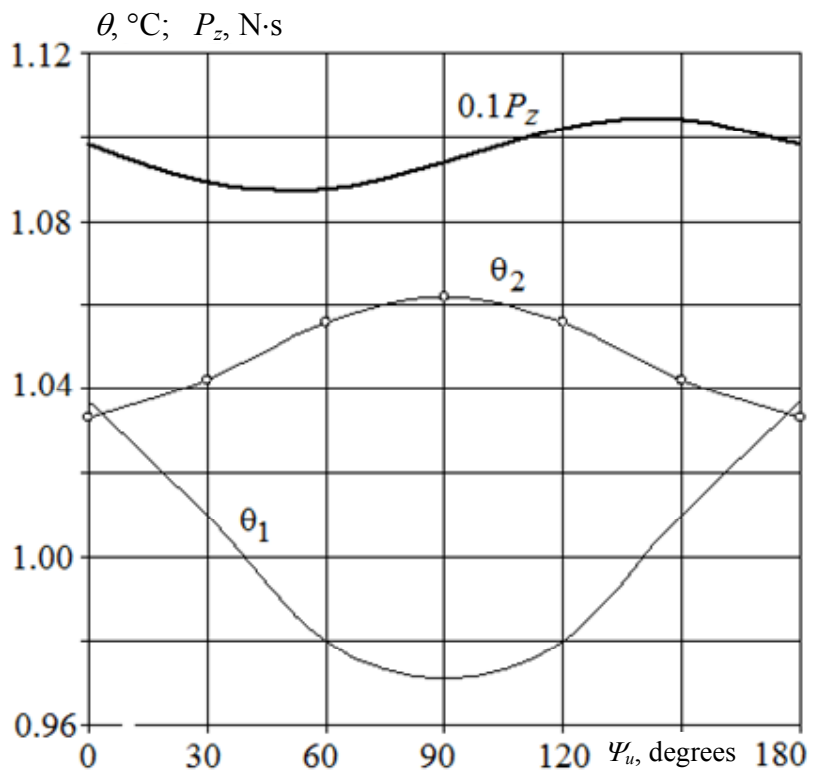

Fig. 3. Dependence of thermal and power indicators of LEMC in shock-power mode on the initial voltage phase of the AC source

To assess the influence of the initial phase of the source voltage, we use the relative change in the value of the indicator $\kappa$ :

$$
\Delta \kappa=2 \frac{\kappa_{\max }-\kappa_{\min }}{\kappa_{\max }+\kappa_{\min }},
$$

where $\kappa_{\max }, \kappa_{\min }$ are the maximum and minimum values of the indicator $\kappa$, respectively.

The minimum value of the value of the impulse of the force $P_{z}$ for the considered converter occurs approximately at $\psi_{u}=50^{\circ}$, and the maximum value - after $90^{\circ}$. The relative change in the value of the force impulse is insignificant and amounts to $\Delta P_{z}=1.5 \%$.

The temperature rise of the windings has an extremum at the center of the considered interval $\psi_{u}$. The temperature rise of the inductor winding at $\psi_{u}=90^{\circ}$ is minimal, and of the armature winding is maximal. The relative changes in thermal indicators are $\Delta \theta_{1}=6.6 \%$ and $\Delta \theta_{2}=2.8 \%$.

Excitation of LEMC in high-speed mode. The high-speed mode of LEMC is characterized by the fact that, under the action of an electrodynamic force, the armature winding, together with the actuation element, moves relative to the inductor winding, causing a weakening of the magnetic coupling between the windings (Fig. 4). In this mode of LEMC operation, the current in the inductor winding has the following features (Fig. 4,a). In the first half-period, the maximum current density in the inductor winding has the highest value $j_{1}=125.2 \mathrm{~A} / \mathrm{mm}^{2}$, but after several periods it reaches a steady-state value $j_{1}=99 \mathrm{~A} / \mathrm{mm}^{2}$ (as when operating with the missing armature winding). The induced current in the armature winding has an oscillatory-damping character with the highest maximum value in the second positive half-cycle.

The indicated character of the flow of currents leads to a significant change in the temperature rise in relation to the shock-force mode of operation of the LEMC. The rise of the temperature of the inductor winding by the end of the considered time interval is $\theta_{1}=0.88{ }^{\circ} \mathrm{C}$ and increases from the moment of connection to the $\mathrm{AC}$ source. The rise of the temperature of the armature winding has the nature of saturation, reaching a significantly lower value $\theta_{2}=0.16{ }^{\circ} \mathrm{C}$ during the considered time.
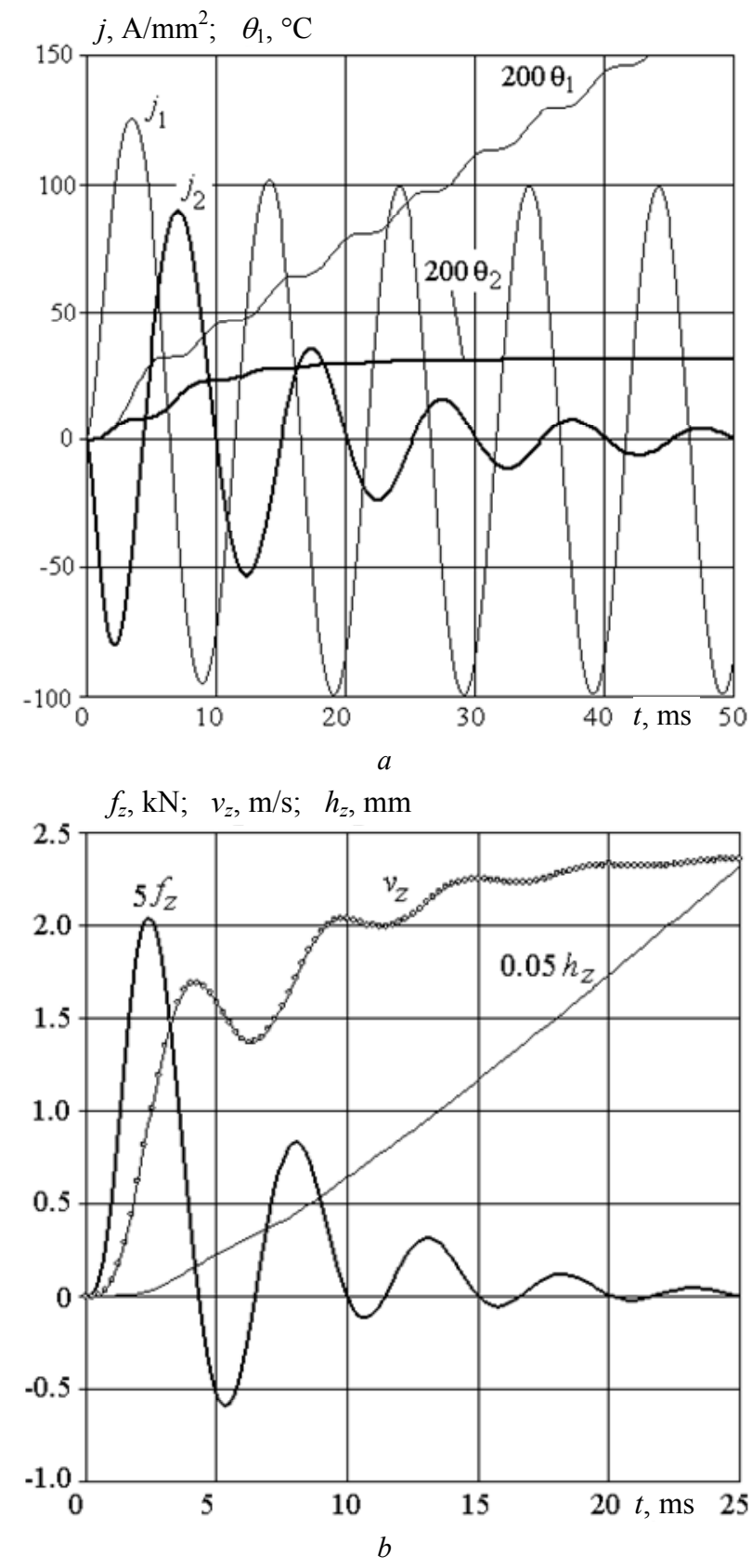

Fig. 4. Electrical, thermal $(a)$ and mechanical $(b)$ characteristics of LEMC when excited in high-speed mode

The mechanical characteristics of LEMC of induction type in high-speed operation mode have the following features (Fig. 4,b). The electrodynamic force $f_{z}$ takes on an oscillatory character with fast decay and a significant predominance of the positive component. The largest value of the force $f_{z}=0.4 \mathrm{kN}$ is less than when the LEMC operates in the shock-power mode. But the value of the force impulse is even more significantly less, 
having $P_{z}=1.25 \mathrm{~N} \cdot \mathrm{s}$ by the end of the considered time interval.

The nature of the change in the speed of the armature winding is influenced by both positive (accelerating) and negative (braking) components of the electrodynamic force. By the end of the considered excitation interval, the speed reaches its maximum value $V_{m}=2.36 \mathrm{~m} / \mathrm{s}$.

The influence of the initial voltage phase on the LEMC indicators is shown in Fig. 5. Compared with the shock-power mode of operation of the LEMC in the range $\psi_{u} \in\left(0 ; 180^{\circ}\right)$, there is no symmetry of the temperature rise of the windings. The relative changes in thermal indicators are $\Delta \theta_{1}=8 \%, \Delta \theta_{2}=1.9 \%$. The maximum armature winding speed takes place at approximately $\psi_{u}=90^{\circ}$. It slightly depends on the initial phase of the voltage (the relative change is $\Delta V_{m}=2.5 \%$ ).

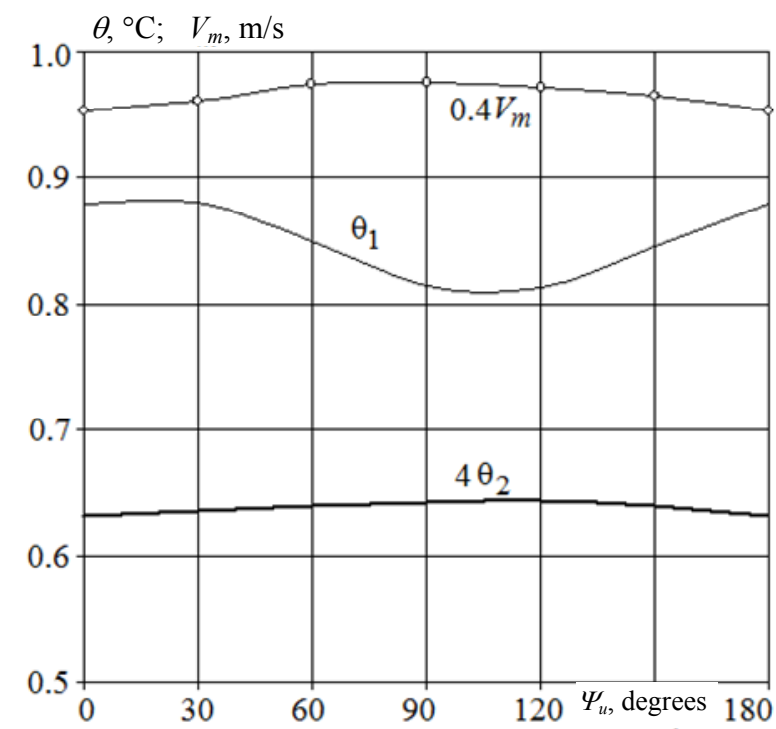

Fig. 5. Dependence of thermal and mechanical parameters of LEMC in high-speed mode on the initial voltage phase of the AC source

Based on the research carried out, the following conclusion can be drawn. Excitation of LEMC of induction type from an $\mathrm{AC}$ source makes it possible to implement new technical applications. For example, when the LEMC operates in the shock-power mode, it is possible to multiply the time of the force action on the actuating element in comparison with the excitation from the capacitive energy storage. Such a long-term force effect is necessary in presses with a large range of impact energies, in drives of cold rolling mills, in vibrating mixers, metering devices, pumps, in test complexes for checking critical equipment for power loads, in magneticpulse devices for pressing ceramic powders, in devices for electrodynamic treatment of welded joints, etc. [9].

Conclusions.

1. A chain mathematical model of the LEMC with excitation from an $\mathrm{AC}$ source has been developed, in which the solutions of equations describing interrelated electrical, magnetic, mechanical and thermal processes are presented in a recurrent form.

2. It is found that when the LEMC operates in the shock-power mode, the maximum value of the current in the inductor winding occurs in the first half-period, and in the inhibited armature winding in the second half-period. The electrodynamic force changes at twice the frequency, taking on both positive and negative values. Since the positive values exceed the negative ones, the value of the impulse of the electrodynamic force increases with each period of the force. Depending on the initial voltage phase, the relative change in the value of the force impulse is $1.5 \%$.

3. It is established that when the LEMC operates in high-speed mode, the current in the inductor winding in the first half-period has the greatest value, but after several periods it takes on a steady state. The temperature rise of the inductor winding increases with the time of connection to the $\mathrm{AC}$ source, and the temperature rise of the armature winding has the nature of saturation. The electrodynamic force has an oscillatory character with strong damping and a significant predominance of the positive component. Depending on the initial phase of the voltage, the relative change in the maximum speed of the armature winding is $2.5 \%$.

Conflict of interests. The authors declare no conflicts of interest.

\section{REFERENCES}

1. Guangcheng F., Wang Y., Xu Q., Xinyi N., Yan Z. Design and analysis of a novel three-coil reconnection electromagnetic launcher. IEEE Transactions on Plasma Science, 2019, vol. 47, no. 1, pp. 814-820. doi: https://doi.org/10.1109/tps.2018.2874287. 2. Go B.-S., Le D.-V., Song M.-G., Park M., Yu I.-K. Design and electromagnetic analysis of an induction-type coilgun system with a pulse power module. IEEE Transactions on Plasma Science, 2019, vol. 47, no. 1, pp. 971-976. doi: https://doi.org/10.1109/tps.2018.2874955.

3. Angquist L., Baudoin A., Norrga S., Nee S., Modeer T. Low-cost ultra-fast DC circuit-breaker: Power electronics integrated with mechanical switchgear. 2018 IEEE International Conference on Industrial Technology (ICIT), 2018, Lyon, pp. 1708-1713. doi: https://doi.org/10.1109/icit.2018.8352439.

4. Vilchis-Rodriguez D.S., Shuttleworth R., Barnes M. Modelling thomson coils with axis-symmetric problems: practical accuracy considerations. IEEE Transactions on Energy Conversion, 2017, vol. 32, no. 2, pp. 629-639. doi: https://doi.org/10.1109/tec.2017.2651979.

5. Kondratiuk M., Ambroziak L. Concept of the magnetic launcher for medium class unmanned aerial vehicles designed on the basis of numerical calculations. Journal of Theoretical and Applied Mechanics, 2016, vol. 54, iss. 1, pp. 163-177. doi: https://doi.org/10.15632/jtam-pl.54.1.163.

6. Liu X., Yu X., Ban R., Li Z. Analysis of the capacitor-aided meat grinder circuits for an inductive pulsed power supply. IEEE Transactions on Plasma Science, 2017, vol. 45, no. 7, pp. 1339-1346. doi: https://doi.org/10.1109/tps.2017.2705179.

7. Gorodzha K.A., Podoltsev O.D., Troshchinsky B.A. Electromagnetic processes in pulse electrodynamic emitter for exciting elastic oscillations in concrete structures. Technical Electrodynamics, 2019, no. 3, pp. 23-28. doi: https://doi.org/10.15407/techned2019.03.023.

8. Yadong Z., Ying W., Jiangjun R. Capacitor-driven coil-gun scaling relationships. IEEE Transactions on Plasma Science, 2011, vol. 39, no. 1, pp. 220-224. doi: https://doi.org/10.1109/tps.2010.2052266.

9. Bolyukh V.F., Shchukin I.S. Lineinye induktsionnodinamicheskie preobrazovateli [Linear induction-dynamic converters]. Saarbrucken, Germany, LAP Lambert Academic Publ., 2014. 496 p. (Rus). 
10. Driga M.D., Weldon W.F., Woodson H.H. Electromagnetic induction launchers. IEEE Transaction on Magnetics, 1986, vol. 22, no. 6, pp. 1453-1458. doi: https://doi.org/10.1109/tmag.1986.1064639.

11. Balikci A., Zabar Z., Birenbaum L., Czarkowski D. Improved performance of linear induction launchers. IEEE Transactions on Magnetics, 2005, vol. 41, no. 1, pp. 171-175. doi: https://doi.org/10.1109/tmag.2004.839283.

12. Bolyukh V.F., Kocherga A.I., Schukin I.S. Investigation of a linear pulse-induction electromechanical converter with different inductor power supply circuits. Electrical Engineering \& Electromechanics, 2018, no.1, pp. 21-28. doi: https://doi.org/10.20998/2074-272x.2018.1.03.

13. Bolyukh V.F., Katkov I.I. Influence of the Form of Pulse of Excitation on the Speed and Power Parameters of the Linear Pulse Electromechanical Converter of the Induction Type. Volume 2B: Advanced Manufacturing, Nov. 2019, 8 p. doi: https://doi.org/10.1115/imece2019-10388.

14. Bolyukh V.F. Effect of electric conducting element on indicators of linear pulse electromechanical converter induction type. Technical Electrodynamics, 2020, no. 3, pp. 22-29. doi: https://doi.org/10.15407/techned2020.03.022.

15. Bolyukh V.F., Oleksenko S.V., Schukin I.S. Efficiency of linear pulse electromechanical converters designed to create impact loads and high speeds. Electrical Engineering \&
Electromechanics, 2015, no. 3, pp. 31-40. doi: https://doi.org/10.20998/2074-272X.2015.3.05.

16. Bolyukh V.F., Shchukin I.S. The thermal state of an electromechanical induction converter with impact action in the cyclic operation mode, Russian Electrical Engineering, 2012, vol. 83, no. $10, \quad$ pp. 571-576. doi: https://doi.org/10.3103/S1068371212100045.

Received 25.10.2020

Accepted 05.12.2020

Published 25.02.2021

V.F. Bolyukh ${ }^{1}$, Doctor of Technical Science, Professor,

Yu.V. Kashansky ${ }^{1}$, Graduate Student,

I.S. Schukin ${ }^{2}$, Ph.D., Associate Professor,

${ }^{1}$ National Technical University «Kharkiv Polytechnic Institute», 2, Kyrpychova Str., Kharkiv, 61002, Ukraine, e-mail: vfbolyukh@gmail.com

${ }^{2}$ Firm Tetra, LTD,

18, Gudanova Str., Kharkiv, 61024, Ukraine, e-mail: tech@tetra.kharkiv.com.ua

How to cite this article:

Bolyukh V.F., Kashansky Yu.V., Schukin I.S. Features of excitation of a linear electromechanical converter of induction type from an AC source. Electrical Engineering \& Electromechanics, 2021, no. 1, pp. 3-9. doi: 10.20998/2074-272X.2021.1.01. 